\title{
Students' Perceptions of Teacher Talk Through Online Learning During Covid-19 Pandemic
}

\author{
Teika Ameiratrini* Eri Kurniawan
}

\author{
Universitas Pendidikan Indonesia, Bandung, Indonesia \\ *Corresponding author. Email: teikaameiratrini@upi.edu
}

\begin{abstract}
Today's case of coronavirus pandemic forces the teaching and learning process to be conducted online. The students' perceptions of ultimate English classroom interaction especially on how teacher uses their talk are considered a crucial issue to be investigated. Many students feel reluctant to be active during online learning due to the limited opportunities offered in the online learning activity. This paper is aimed to analyze students' perceptions of teacher talk through online learning during the covid-19 pandemic. The data were collected from an interview with three students. Questionnaires were also distributed to 36 students concerning supporting the students' perceptions about teacher talk. A qualitative design was used to give an in-depth analysis. The results indicate that students mostly agree that teacher uses balanced portion in praising, motivating, clarifying their idea during a learning activity. Related to how the class is conducted through online learning, students dominantly perceived that the learning is not significant enough due to the issue of accessibility that becomes the major factor influencing the success of classroom interaction.
\end{abstract}

\section{Keywords: Classroom interaction, online learning, students' perception, teacher talk}

\section{INTRODUCTION}

Due to the current situation that the world faces nowadays, the outbreak of the Covid-19 pandemic has brought many adjustments in every aspect of life, including the education sector. The teaching and learning process starts to fit in with this situation. World Health Organization in 2019 suggests that for each country, social distancing and physical distancing have built decisions to enforce (as cited in Rasmitadila et al., 2020). The situation results in the change in teaching and learning regulations in some countries. The government comes up with a new policy that requires the education system to be conducted online. It involves the use of some communication platforms, such as Zoom and Google Classroom. The implementation of online learning has brought new challenges to classroom interaction to distinctive learning results.

The adjustment of the current situation impacts the result of an interaction between teachers and students. The success of language learning is determined by how the classroom interaction runs. In the English Foreign Language (EFL) classroom, teachers play an essential role in engaging with students since they have a significant portion of the class time used to provide guidance, clarify activities, and check students' comprehension of the target language (Sinclair \& Brazil as cited in Yanfen \& Yuqin, 2010). In running a successful classroom interaction, teacher talk is an essential weapon of classroom interaction does hold a significant role in leading active and interactive classroom activity. Through the chance of conducting the learning activity online, the challenges that teachers face may occur.

The teacher has a crucial role in managing the classroom setting. Based on Goffman (1976), a language classroom has its own main rules that provide the teacher with some authority to choose who speaks, determine on what topic, and decide for how long speaking. Teachers have an enormous power to rule. Practical teacher talk creates a balanced surrounding and fosters a more positive relationship between teacher and student. This situation provides more opportunities for students to engage in the language learning process actively. In nowadays issue, several teachers have a high intention to create a conversational mode of classroom communication concerning its interaction. However, they are stuck on the learning goals that disallow creating an uncontrolled classroom conversation (Heath, 1978, p. 11). It is necessary for teachers to be successfully 
creating the inexhaustible interaction vibe since classroom interaction considers to be alive as it brings excitement and joys for the students to be a dare in speaking.

Engaging students in language learning activities is indeed needed to help them practice the target language. According to Bonwell and Eison (1991), stimulating a discussion is one of the most typical ways of engaging students in active learning. Therefore, Abdullah, Bakar, and Mahbob (2012) suggest that it is essential for teachers to establish a conducive learning setting that triggers the students to participate in the classroom actively. Many students are determined to speak passionately, yet they are reluctant to speak up (Abdullah et al., 2012). In the current issue, passionate students are not allowed to use their talk in classroom interaction since teachers still dominate their talk in classroom communication. Milal (2011), in her research, found the case where teachers are too controlled and dominated during the classroom interaction of English subjects. The domination of teacher talk should not be an obstacle for students to be more active in participating in learning activities. The excitement of the student and the eagerness to participate in the classroom through these verbal contributions would create a supportive classroom setting (Davis, 2009).

Concerning online class learning these days, teachers may face real challenges - the use of their talk impacts the success of classroom interaction. Students, as part of the interaction, may have various assumptions towards this unusual way of learning. They might have had different perspective of teacher talk online compared to offline mode. How they perceive their teacher talk indeed gives a contribution to the improvement for the teacher in developing and reflecting their teaching and learning results. Therefore, this study tends to explore how students perceive teacher talk during online learning.

\section{LITERATURE REVIEW}

\subsection{Classroom Interaction}

Interaction is described as the communication process; it involves acts, actions, or practices of two or more individuals to influence each other's' experiences or intentions (Asmara, 2007; Aisyah, 2016; Brown, 2001; Rummel, 1976). The term classroom interaction relates to the interaction between teachers and students in engaging, among others, in a learning activity. Descriptions of classroom interaction focused initially on the teacher's words, particularly teacher questions, and the individual reactions elicited teachers' response and turn allocation behaviour. Goronga (2013) adds that classroom interaction makes the students involved in the teaching and learning process. It means that classroom interaction encourages students to get involved.

\subsection{Flanders Interaction Analysis Categories System}

The interaction between teacher and students in the classroom focus on the patterns and system of communication is built and developed by Flanders (1970) as cited in Nunan (1989, p. 149). The interaction analysis categories suggested the basics of structured classroom interaction analysis that are built by Flanders (1970), includes teacher's talk and student's talk, which is named Flanders Interaction Analysis Categories. These interaction analysis categories are the breakthrough of structured classroom observation that consists of ten categories of classroom interaction analysis (Nunan, 1989, p. 149). Li, Shouhui and Xinying (2011, p. 1-8) add that it is assumed in FIAC that the teaching behavior of a teacher and learner's response mainly interact through spoken words as various verbal interactions that present continuously. FIACS has been widely used by researchers in analysing the system of interaction to study the happenings in a classroom when a teacher teaches. This system has been widely used for observing classroom interaction and becomes the basis for many other systems developed later on.

\subsection{Teacher Talk in FIACS}

In relation to creating an interactive foreign language classroom, it is essential to pay attention to teacher talk employed by the teacher in the classroom. This is supported by Yanfen and Yuqin (2010), who stated that the appropriate teacher talk could create harmonious atmospheres, and at the same time, promote a more friendly relationship between teachers and students, and consequently create more opportunities for interactions between the teachers and the students. Flanders (1970, p. 5), as quoted in Hai and Bee (2006), Flanders Interaction Analysis Category System (FIACS) classified teacher talk into seven types in two categories: direct influence and indirect influence. Direct influence type covers lecturing, giving directions, and criticizing or justifying authority. Meanwhile, the indirect influence consists of accepting feelings, praising or encouraging, accepting or using pupils' ideas, and asking questions.

\subsection{Students' Perception}

Perception is someone's thought about something that they learn to measure their attitude toward using something, whether they agree or not about the method or about something that they learn (Hong, Ridzuan, \& Kuek, 2003). It means that students have their own opinion toward something that gets from the teachinglearning process and how they reach toward it. Students' perceptions are students' point of view toward something that happened in the learning process and produce it with suggestions or arguments for teachers or classmates to improve their learning process (Sidhu, 2003, p.15). 


\section{METHOD}

\subsection{Research Design}

This study is intended to analyse the students' perceptions about teacher talk through online learning. The method of research applied in this study was qualitative. The descriptive analysis was used to elaborate on the data using detailed information. The data gathered was descriptively analysed in-depth information. The research was carried out during the transformational teaching-learning activities through elearning.

\subsection{Participants}

Participants in this study were 36 students from the second grade of one of the Senior High School in Bandar Lampung. The school chosen was one of the best schools in Bandar Lampung. Therefore, it was expected to have students being active and interactive through the classroom interaction. Among those 36 students, 3 chosen students were interviewed to support the data.

\subsection{Data Collection}

In dealing with the research design, the researcher used a descriptive design. In gathering the data, the researcher used two kinds of instruments, namely questionnaires and interviews. All the instruments were conducted online. The online platforms used in this research were Zoom and Google Classroom. Both of these two online platforms were used twice. The different uses of the online platforms were distinguished by the different lesson plans.

The questionnaires were distributed to 36 students. The questionnaires consist of students' opinions about how the teacher performs their talk in engaging students in classroom interaction. They are adopted from Putri (2015) with some of the adjustment regarding to the online teaching and learning activity. The result of questionnaires was calculated using Likert scale. The questionnaires provide five kinds of options; those are strongly agree, agree, neutral, disagree, and strongly disagree.

The other instrument used is the interview. The researcher conducted the interview to some certain students. The interview was expected to give a different way of view in seeing how the teacher builds up the interaction between all the students together in one session of classroom interaction online. The interview was recorded and transcribed to be analyzed in descriptive findings.

\subsection{Data Analysis}

The data of the study were analysed using descriptive analysis to identify the detail of the information given by the participants. The credibility and dependability were considered in this study. The data were also analysed using percentage and the relevant categories of teacher talk and classroom interaction.

\section{FINDINGS AND DISCUSSION}

This research attempts to find students' perceptions of how their teacher uses their talk in classroom interaction during online learning. Direct and indirect interaction were analysed through students' perceptions based on questionnaires and interviews. Direct influence type covers lecturing, giving directions, and criticizing or justifying authority. Meanwhile, the indirect influence consists of accepting feelings, praising or encouraging, accepting or using pupils' ideas, and asking questions

\subsection{Accepting Feelings}

Pertaining to the matter of students' opinion of how teacher accepts students' feeling, the questionnaires provide two statements related to it. The first statement says that the teacher listens to all students' feelings toward anything about the lesson. Based on the result of the questionnaire, almost half of students did agree with the idea of how teacher listens and understands about how students respond to the input given. The value number of those who agreed was $38.9 \%$, yet $30.6 \%$ of students in the class decided to give neutral ideas to this opinion.

The second statement says the teacher gives a fast response when students happen to have a question or ask about an unclear explanation. The highest value obtained by this idea is $44.4 \%$ ( 16 students). This notion presents the meaning that the teacher is good at responding to students' confusion of unclear explanation. However, there is still a number of students who strongly disagreed with this view. 2 of 36 students in the class have a slightly different idea toward this statement. They strongly disagree with noticing that teacher gives a fast response to those who have not comprehended the material well. This situation could be caused by their personal experience where students do not get a satisfying response from the teacher to gain a more straightforward explanation of the material.

The result of questionnaires shows that students mostly perceived that they feel comfortable enough with the way how teacher accepts their feeling by listening to their feelings as well as giving fast response to their questions about unclear explanation. Gharbavi and Iravani (2014) state that the teacher is supposed to make students more courageous to get involved in the interaction by creating a comfortable environment. 


\subsection{Praising and Encouraging}

According to the questionnaire result, half of the students out of the total number in the class agreed that they had the experience of being praised and encouraged by the teacher as they were involved in the answer questioning session during the class interaction. There are nine students who even strongly agreed with the statement. Praising is considered a positive acknowledgment that a teacher needs to give to students (Nugrahaeni, 2018). The interview administered to the students supports the idea that students like to be praised by the teacher. They acknowledged that praising was one of the ways of how teachers valued students' existence and their effort to be active in classroom activity.

\section{Excerpt 1}

AA : "Dipuji guru itu membuat tambah semangat Belajarnya, kak. Jadi saya suka"

KSR : "Saya senang ketika guru mengapresiasi usaha saya untuk menjadi aktif di kelas."

IF :"Ketika dipuji, saya jadi merasa sangat dihargai."

On the next statement, sixteen students of the whole class agreed that the teacher often motivated the students to give ideas. Yet, six students preferred of being lack of motivation in giving their idea. It might be occurred by many factors such as anxiety that causes them more doubt in showing their idea in getting involved in classroom interaction. The role of teacher should have taken the part of giving more encouragement in order to build students' confidence to be more active. According to Mulyati (2013), encouragement boosts students to be more selfmotivated. Through the interview, two of students had the same opinion that teacher did motivate them to be more active, and one of them stated that the encouragement comes from the preference of the lesson that the students had.

Excerpt 2

AA :"Yes, sometimes she makes me active."

KSR : "Iya, guru membuat saya aktif."

IF : "Yes, I am active, because I like the lesson."

Based on these two statements mostly agreed by the students, it indicates that the teacher praises and motivates them intensely during the learning activity.

\subsection{Accepting or Using Ideas}

On the statement referring to accepting or using ideas, half of the students in the class agreed that the teacher gives feedback to how students feel towards the lesson explained. Eight students in the class are confused; therefore, they chose to be neutral without giving any opinion. The value of $16.7 \%$ of students in the class disagreed that the teacher responds to students' feelings of anything about the lesson. The way of how the teacher shows verbal interaction can be seen from how she modifies or paraphrases the students' ideas. As it is found on the questionnaires, students' opinion of how teacher uses their idea is still low. The observation has a firm consistency as to how students respond to this matter. From the observation, the teacher rarely modifies or clarifies students' idea. Students might feel doubt about their ideas, since the teacher does not give feedback on it. It could be implied that students' confidence might be decreased because of a lack of improvement from teachers to justify their idea.

\subsection{Asking Questions}

Asking questions is considered as one of the aspects of teacher talk that majorly shown in classroom interaction. Based on the statement that says that teacher asks questions to students at the beginning of the new learning material to introduce it, it is revealed that $28 \%$ of students had the opinion of being disagree and neutral. It means that students were not used to have brainstorming to activate their schemata.

For the next statement where it mentions that teacher always does-asking answering about the lesson with students, students majorly agreed with this idea. The value number of students, $41.7 \%$ (15 students), agreed that teacher actively gives question during learning activities. It shows that teacher actively conducts the activities involving students' participation in asking and questioning about the material learnt. The consistent result is gained by students' answers in the interview. Regarding to their perception about teacher giving questions, three of the interviewees give similar answers.

\section{Excerpt 3}

AA : "I like being asked questions by the teacher." "Questions enable to broad our ide and encourage to be braver in speaking in front of many people in the class."

KSR : "I feel appreciated when teacher asks me Questions, I prefer questions that broad my idea"

IF : "Sometimes I feel like I don't understand the lesson being taught by the teacher, therefore the teacher asks me."

Regarding to one of the students interviewed, he assumed that given question by the teacher implied that he was considered to be confused-look student in the class. He thought that being chosen to answer the question means that the teacher might have a perception the students had not understood enough about the material delivered. Therefore, it causes students' anxiety to show more interaction in the class. In fact, the teacher initiates to give question in more often, as the result of expecting to create more interaction than conducting activities (Irmayani \& Sofeny, 2017). 


\subsection{Lecturing}

The first statement referred in the questionnaire mentions that teacher explains the new learning material directly to students without asking questions to the students first whether they have understood or not. Apparently, the data shows that the biggest number of percentages was on disagree level. Sixteen out of thirtysix students were found being disagree. It leads to the assumption where teacher does not give comprehensible explanation while lecturing the material to the students. She does not function the use of their talk to sum up the previous lesson before jumping on the next lesson.

On the second statement, it turns out that thirteen out of thirty-six students mostly agreed that teacher uses most of their time explaining the learning material. 10 students even strongly agreed that teacher does take up too much time in delivering the material. Flanders as cited in Irmayani and Sofeny (2017) supports this finding by stating that teacher takes up almost $75 \%$ of speaking up and spending little time to learn students' expression. Teacher's lecture is included in the major features characterized of teacher talk based on Flanders. The large portion of teacher lecturing has been found in many previous studies. Suryati as cited in Nasir, Yusuf, and Wardana (2019) pointed out that most of the time is spent mostly by teachers in lecturing with limited admission of learning process of students, mistakes made by students, and students' misinterpretation. The interview demonstrates a supporting result to the questionnaire.

Excerpt 4

AA : "She talks too much for the needed things to deliver."

"Teacher spends $80 \%$, and students spend $20 \%$ "

KSR : "She talks as much as she should, not too much not less."

"Teacher has $60 \%$ portion, and students have $40 \%$."

IF : "She talks too much not talk less."

"Teacher is $70 \%$, students are $30 \%$."

As stated by the interviewees, their statements related to teachers' lecturing portion are almost persistent. In accordance with questionnaire result and the consistency to the interview result, it can assume that students perceive that teacher takes up too much time talking during classroom interaction.

In the opinion of how teacher uses their talk primarily lecturing during online learning, 17 out of 36 students agree that teacher delivers a clear and comprehensible material explanation through online platforms. The clarity of lesson delivery by teacher is comprehensible enough, even though the learning activity is conducted online. However, there are ten students who decide to give neutral opinion toward this matter. It could be coming from students' confusion due to the new way of learning that they had just adjusted. However, the students might feel that this online learning less effective enough because teacher tend to give them assignments without giving further explanation.

\section{Excerpt 5:}

AA : "the teacher only uploaded the material and assigned us to learn by ourselves, and we were directly required to complete the task. Meanwhile, as the class was conducted offline, the teacher would explain the material first, right after that she gave us assignments to do. The advantage of having online class also comes from the inability to directly interact with teachers and other friends in the class."

Students also perceived that there was less engagement during this online learning that might be caused by the limited opportunities for students to be more active. Teacher should have prevented this case by having knowledge of the effect of factors on the participation of online learning that will help overcome the problems and provide all students with equal opportunities to get engaged (Lie et al., 2020).

Regarding to the online learning that occurs nowadays, the clarity and comprehensible learning material is undoubtedly comprehensible enough for students to process. Seventeen students out of thirty-six agree that teacher is successfully good at explaining the learning material even though the classroom activity is conducted through online platforms. Keeping up with the online learning situation, the expectation of having an alive and interactive learning activity must be there for students. Twelve out of thirty-six students are found being agree that teacher has been successful enough in wrapping up an alive and interactive class activities. Nine students in the class have slightly different viewpoint in one way or another. Nine of them strongly disagree that the teacher provides innovative ways of learning in online platforms. In building an effective learning activity, students' enthusiasm is acknowledged as one of the major elements for the success of language learning process. Students might have lost their enthusiasm; therefore, the teacher should improve their interaction engagement and participation (Rasmitadila, et al. 2020). More enthusiastic engagement in online learning would be facilitated by the use of different instructional techniques, including the use of various media. After all, students perceive that the material delivery is comprehensible enough, yet some of the students do assume that they lack enthusiasm in getting involved in classroom interaction. 


\subsection{Giving Directions}

Data about students' perception of the aspect on how teacher gives direction show that $12(33,3 \%)$ students agreed with the statement mentioning that teacher instructs students to listen to the teacher's explanation. Whereas, a number of students, 11 students, gave their neutral opinion about this matter. They might not be so assured whether the teacher asks them to listen to the explanation. The data implies that in some cases, teacher might not instruct students to pay more attention to what the teacher discussed about in front of the class. In line with Putri (2015), students assumed that teacher only instructed those who might have a few lesson inputs as she demonstrated something in the class. It can be assumed further that giving direction expresses discipline issues as the teacher emphasizes the students to pay attention more (Amidon \& Giammatteo, 1965).

Almost half number of students, 12 students, agreed and gave neutral assumption toward the statement that says teacher always gives directions or orders to students to sit in groups, answer questions, come to the front of the class, etc. The balanced number of perceptions between being agree and neutral might be caused by different experiences of students in the class. In line with Holmes (1983 cited in Putri, 2015), teacher's direction is indeed dominantly in types of imperatives and declaratives. Therefore, correlated to teacher asking students to sit in a group and other are considered typical in teacher talk.

\subsection{Criticizing or Justifying Authority}

The other view of students is about the portion of teachers criticizing and justifying the authority. Approximately half of students in the class, 15 students (41.7\%), agrees that teacher often clarifies or improves the students' ideas. It implies that students get the criticism for their behaviour which might need correction from the teacher.

A surprising number of responses coming from the statement mentioning that teacher often criticizes the students' behaviour. 17 out of 36 gave neutral perception. It might be caused by their confusion whether teacher actually gives the critics towards students' behaviour or not. The perception leads to the assumption of disagreement, since 11 students disagreed that teacher does criticize student's behaviour. It implies that teacher tends not to give any criticism to students' behaviour.

Last perception is towards the idea that says teacher always comments and corrects students' unacceptable behaviour to the acceptable one. It seems that half of students' total number in the class namely 16 students are confused, since they gave neutral response to this matter. 11 students agree to this. And some of them are found being disagree.

\section{CONCLUSION}

To conclude, the results of the research revealed that students frequently agreed with the statements of questionnaires leading to teacher's direct and indirect influences. The students mostly agreed that teacher used balanced portion in praising, motivating, clarifying their idea during learning activity. However, most students also perceived that the teacher still took up too many times in lecturing and giving questions which resulting to less students' interaction in the classroom occurred. In accordance with how teacher gives them criticism towards their behaviour, most students gave neutral perspective about the idea of teacher comments and corrects students' behaviour.

Moreover, related to the matter of online platforms conducted through learning activity, students dominantly perceived that the learning system was not effective enough due to the major factor namely the accessibility of how teacher created alive interaction among other students as well as to the teacher. According to questionnaire regarding to teacher's creativity, most of students assumed that teacher's still lack creativity to create more engaging activities. Some students also assumed that teacher tended to make students do the assignments without explaining the material clearly. Students perceived that they got more difficulties in comprehending the material due to that typical situation.

\section{REFERENCES}

Abdullah, M. Y., Bakar, N. R. A., \& Mahbob, M. H. (2012). Students' participation in classroom: What motivates them to speak up? Procedia - Social and Behavioral Sciences, 51, 516-522. https://doi.org/10.1016/j.sbspro.2012.08.199

Aisyah, N. (2016). An analysis of teachers' talk in an EFL classroom. Journal of English and Education, 4(2), 63-79.

Amidon, E., \& Giammatteo, M. (1965). The verbal behavior of superior teachers. The Elementary School Journal, 65: 283-285.

Asmara, T. R. (2007). An analysis on the speaking classroom interactions at the tenth grade of SMA Negeri 7 Surakarta in the academic year 2006/2007 (Unpublished bachelor's thesis). Teacher Training and Education Faculty, Sebelas Maret University.

Bonwell, C. C., \& Eison, J. A. (1991). Active learning: Creating excitement in the classroom. Jossey-Bass.

Brown, H. D. (2001). Teaching by principle: An introduction approach to language pedagogy. New York: A Pearson Education Company.

Davis, B. G. (2009). Tools for teaching (2nd ed.). San Fransisco: Jossey-Bass.

Flanders, N. A. (1970). Analyzing teacher behavior. New York: Addison-Wesley Publishing Co.

Gharbavi, A., \& Iravani, H. (2014). Is teacher talk pernicious to students? A discourse analysis of teacher talk. Procedia-Social and Behavioral 
Sciences,

98 https://doi.org/10.1016/j.sbspro.2014.03.451

Goffman, E. (1976). Replies and responses. Language in Society. 5(3), 257-313. https://doi.org/10.1017/s0047404500007156

Goronga, P. (2013). The nature and quality of classroom verbal interaction: Implications for primary school teachers in Zimbabwe. Academic Research International, $\quad 4(2), \quad 431-444$. http://www.savap.org.pk/journals/ARInt./Vol.4(2)/ 2013(4.2-45).pdf

Hai, S. K., \& Bee, L. S. (2006). Effectiveness of interaction analysis feedback on the verbal behavior of primary school mathematics teachers. Malaysian Journal of Educators and Education, 3(2), 115-128. http://eprints.usm.my/34330/1/8_See_(115128).pdf

Heath, S. B. (1978). Language in education: Theory and practice. No. 9

Hong, K-S., Ridzuan, A. A., \& Kuek, M-K. (2003). Students' attitudes toward the use of the internet for learning: A study at university in Malaysia. Educational Technology \& Society, 6(2), 45-49. https://www.jstor.org/stable/jeductechsoci.6.2.45

Irmayani, \& Sofeny, D. (2017). Students' perceptions towards teacher talk in English classrooms. Seminar Nasional Sistem Informasi, 1(1), 223-237. https://jurnalfti.unmer.ac.id/index.php/senasif/artic le/download/108/93

Li, L., Shouhui, Z., \& Xinying, C. (2011). Beyond research: Classroom interaction analysis techniques for classroom teachers. Paper presented at the 4th Redesigning Pedagogy International Conference, Singapore.

Lie, A., Tamah, S. M., Gozali, I., Triwidayati, K. R., Utami, T. S. D., \& Jemadi, F. (2020). Secondary school language teachers' online learning engagement during the Covid-19 pandemic in Indonesia. Journal of In-formation Technology Education: Research, 19, 803-832. https://doi.org/10.28945/4626

Milal, A. D. (2011). Indicators of practice of power in language classrooms. TEFLIN Journal, 22(1), 1-15. http://journal.teflin.org/index.php/journal/article/vi ew/15

Mulyati, A, F. (2013). A study of teacher talk and student talk in verbal classroom interaction to develop speaking skill for young learners. Journal of English and Education, 1(1), 1-10.

Nasir, C., Yusuf, Y. Q., \& Wardana, A. (2019). A qualitative study of teacher talk in an EFL classroom interaction in Aceh Tengah, Indonesia. Indonesian Journal of Applied Linguistics, 8(3), 525-535. https://doi.org/10.17509/ijal.v8i3.15251

Nugrahaeni, J. (2018). Students' perceptions toward teacher's talk in English classroom (the study at the eleventh grade students of SMKN Jenawi Karanganyar in the academic year 2017/2018) (Unpublished bachelor's thesis). The State Islamic Institute of Surakarta: Indonesia.

Nunan, D. (1989). Understanding language classrooms: A guide for teacher initiated actions. Cambridge: Prentice Hall International Ltd.

Putri, D. S. (2015). The analysis of teacher talk and characteristic of classroom interaction in English as a foreign language classroom (Unpublished bachelor's thesis). Universitas Pendidikan Indonesia, Bandung.
Rasmitadila, Aliyyah, R. R., Rachmadtulla, R., Samsudin, A., Syaodih, E., Nurtanto, M., \& Tambunan, A. R. S. (2020). The perceptions of primary school teachers of online learning during the COVID-19 pandemic period: A case study in Indonesia. Journal of Ethic and Cultural Studies, 7(2), 90-109. https://doi.org/10.29333/ejecs/388

Rummel, R. J. (1976). Understanding conflict and war (Vol. 2). Beverly Hills, CA: Sage Publications.

Sidhu, G. K. (2003). Literature in the Language Classroom: Seeing through the eves of Learners. In: Ganakumaran \& Edwin Malaci (Eds). Teaching of Literature in ESL/EFL context. Pp.88-110. Petaling Jaya:Sasbadi-Melta ELT Series.

Yanfen, L., \& Yuqin, Z. (2010). A study of teacher talk in interactions in English classes. Chinese Journal of Applied Linguistics, 33(2), 76-86. 